\title{
Iluminasi Panel Surya pada Satelit Orbit Rendah Ekuatorial
}

\author{
DESTI IKA SURYANTI, SRI RAMAYANTI, MOHAMMAD MUKHAYADI \\ Pusat Teknologi Satelit LAPAN \\ Email: desti.ika@lapan.go.id
}

Received 8 Mei 2019 | Revised 19 Juni 2019 | Accepted 10 Juli 2019

\begin{abstract}
ABSTRAK
Desain satelit telah berkembang ke arah miniaturisasi untuk mengurangi biaya peluncuran. Satelit kecil menyediakan platform berbiaya rendah untuk misi luar angkasa. Salah satu permasalahan utama satelit kecil adalah terbatasnya ketersediaan daya. Karena ketersediaan daya diperlukan agar subsistem satelit dapat bekerja, maka pada proses desain satelit perlu dilakukan analisis dan estimasi ketersediaan daya selama satelit mengorbit dengan tetap mempertahankan kekompakan dan volume yang diberlakukan oleh standar. Penelitian ini bertujuan untuk mengetahui kondisi iluminasi matahari pada panel surya dari berbagai alternatif desain penempatan sehingga diperoleh sebuah desain yang efisien. Iluminasi maksimum sebuah panel surya triple junction yang terpasang secara body mounted pada satelit kurang lebih sebesar 60\%. Berdasarkan hasil penelitian ini, kombinasi pemasangan 3 body mounted panel surya dan 2 simple deploy panel surya menghasilkan persentase iluminasi dua kali lipat dibandingkan 5 body mounted panel surya.
\end{abstract}

Kata kunci: panel surya triple junction, iluminasi, body mounted, simple deploy, daya

\begin{abstract}
Satellite design has envolved towards miniaturization to reduce launch costs. Small satellites provide a low-cost platform for space missions. One of the main problems with small satellites is the limited availability of power. Because the availability of power is needed so that the satellite subsystem can work, the satellite design process needs to analyze and estimated power availability as long as the satellite orbits while maintaining the compactness and volume imposed by the standard. This study aims to determine the conditions of solar illumination on solar panels from various alternative design placements in order to obtain an efficient design. Maximum illumination of triple junction solar panel mounted on a small satellite is approximately $60 \%$. Based on the results of this study, the combination of installing 3 body mounted solar panels and 2 simple deploy solar panels produced twice the illumination percentage compared to 5 body mounted solar panels.
\end{abstract}

Keywords: solar panel triple junction, illumination, body mounted, simple deploy, power 


\section{PENDAhuluan}

Satelit merupakan suatu benda yang berputar di ruang angkasa dan mengelilingi bumi. Satelit dapat berperan sebagai stasiun radio yang menerima dan memancarkan kembali, memproses dan memancarkan kembali frekuensi radio sehingga dapat digunakan sebagai wahana komunikasi. Suatu misi satelit umumnya terdiri dari wahana antariksa dan stasiun bumi (ground station) yang mengoperasikan dan mengendalikan satelit beserta link di antaranya (Ray, 1963).

Fokus pada pengurangan biaya menggunakan satelit kecil dan konstelasi satelit kecil dalam misi pengamatan bumi dan ruang komunikasi dijelaskan oleh banyak karya. Satelit kecil biasanya memiliki keterbatasan dalam ketersediaan daya untuk dapat menjalankan setiap misinya. Sistem daya listrik pada satelit berfungsi mensuplai daya listrik ke seluruh sistem wahana antariksa sejak awal operasi sampai dengan akhir operasi dari hidup satelit (Karim \& Hasbi, 2013). Sistem wahana antariksa yang harus dipenuhi kebutuhan dayanya tersebut terdiri atas dua bagian, sistem bus satelit dan sistem muatan (payload) satelit. Dalam operasi harian, satelit menggunakan panel surya sebagai pembangkit energi utama dan menyimpan energi ke dalam sistem baterai. Baterai tersebut akan digunakan pada saat kebutuhan daya listrik yang sangat tinggi atau pada saat terjadi eclipse (James, dkk., 1999).

Gambar 1 menunjukkan perkembangan efisiensi tertinggi terbaru berbagai teknologi sel surya di dunia. NREL melakukan pembaharuan data secara periodik efisiensi tertinggi dari masingmasing teknologi sel surya. Sebagai contoh grafik yang penulis unduh 19 Februari 2019, nilai efisiensi tertinggi dari seluruh teknologi yang ada dipegang oleh perusahaan Solar Junction (44.0\%) dengan teknologi multijunction sel surya.

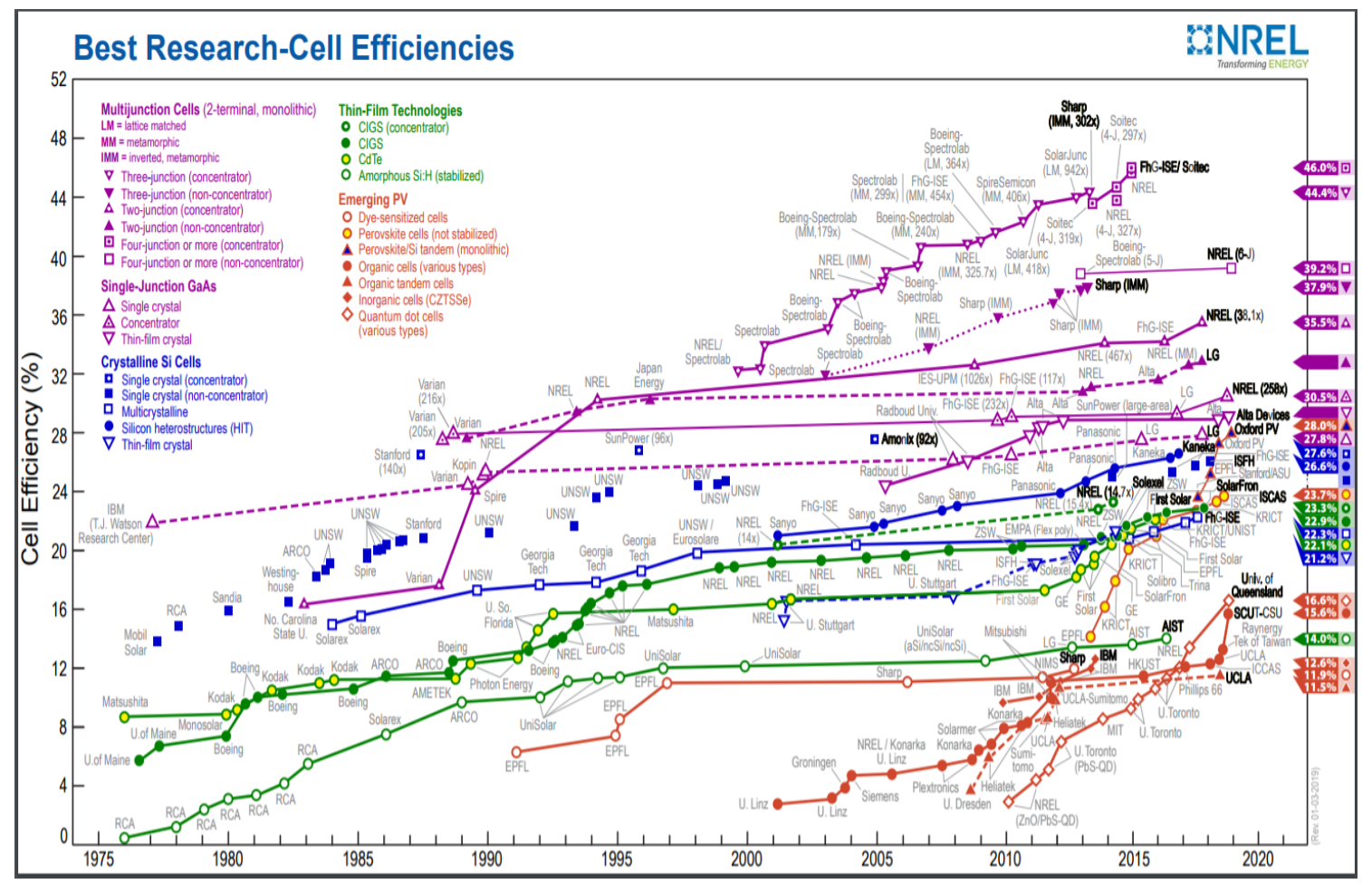

Gambar 1. Grafik Perkembangan Rekor Efisiensi Sel Surya (NREL, 2019) 
Sel surya dapat diklasifikan menjadi 4 generasi (Luceño-Sánchez, dkk., 2019). Generasi pertama merupakan teknologi silikon kristalin, yaitu monokristalin dan polikristalin serta Gallium Arsenide. Generasi kedua termasuk sel surya silikon amorf (a-Si) dan sel surya lapisan tipis silikon mikrokristalin ( $\mu \mathrm{c}-\mathrm{Si})$, cadmium telluride/cadmium sulphide (CdTe/CdS) dan sel surya copper indium gallium selenide (CIGS). Generasi 3 termasuk teknologi berdasarkan senyawa termasuk lapisan nanokristalin, dot quantum aktif, lapisan multi tandem atau ditumpuk dari material inorganik berdasarkan material III-IV seperti GaAs/GaInP, sel surya organik (polimer) sel surya dyed-sensitized. Generasi 4 mengkombinasikan lapisan polimer tipis yang murah serta fleksibel dengan kestabilan nanostruktur inorganik seperti nanopartikel logam dan logam oksida atau nanomaterial organik seperti karbon nanotube, graphene.

Panel surya yang digunakan memakai multijunction Gallium Arsenide pada Germanium (GaAs/Ge) yang merupakan generasi ketiga. Pada tiap sel surya dipasang shunt diode (internal ataupun eksternal) untuk mencegah terjadinya reverse biasing (Loh, 1991). Material Gallium Arsenide lebih dipilih dibandingkan silikon karena bandgap dari material ini $1.42 \mathrm{eV}$ pada temperatur $300^{\circ} \mathrm{K}$ yang sangat ideal untuk peralatan fotovoltaik. Selain itu, sel surya GaAs lebih cocok untuk diaplikasikan pada temperatur lebih tinggi dibandingkan sel silikon (Anspaugh, 1996). Sel surya GaAs/Ge sangat tahan terhadap degradasi radiasi serta memiliki efisiensi yang tinggi sehingga ideal digunakan untuk aplikasi ruang angkasa (Luceño-Sánchez, dkk., 2019).

Dalam beberapa tahun terakhir telah dilakukan beberapa penelitian yang difokuskan pada maksimalisasi solar generator (Anigstein \& Sánchez Peña, 1998)(Santoni, dkk., 2014). Berbagai solusi telah dilakukan untuk mengoptimalkan konfigurasi dari panel surya, termasuk kemungkinan variasi penempatan susunan panel surya dari permukaan satelit. Mempertimbangkan pentingnya peranan panel surya pada satelit, maka pada proses perancangan satelit memerlukan analisis dan estimasi jumlah daya yang dihasilkan oleh panel surya selama misi satelit di orbit. Berbagai solusi telah dilakukan untuk mengoptimalkan konfigurasi dari panel surya, termasuk kemungkinan variasi penempatan susunan panel surya dari permukaan satelit. Tujuan dari peneltian ini adalah mengetahui kondisi iluminasi matahari pada panel surya dari berbagai alternatif desain penempatan sehingga diperoleh sebuah desain yang efisien.

Analisis dan estimasi pada penelitian ini meliputi dua kondisi, yaitu kondisi daylight dan kondisi eclipse. Dalam hal ini, panel surya harus menghasilkan daya maksimum selama kondisi daylight agar bisa menjaga daya yang digunakan selama kondisi ecplise (Park \& Cha, 2016). Berdasarkan analisis tersebut akan diketahui kebutuhan luasan panel surya beserta konfigurasi penempatan yang tepat untuk memproduksi daya listrik bagi satelit. Luasan panel surya yang terlalu kecil tidak akan mampu mensuplai kebutuhan daya operasi satelit. Sebaliknya luasan panel surya yang terlalu besar dan melebihi kebutuhan akan menambah berat satelit sehingga menambah biaya peluncuran.

Perancangan panel surya akan berupaya mendapatkan jumlah dan berat minimum panel surya untuk memenuhi kebutuhan daya satelit. Upaya minimalisasi jumlah dan berat panel surya bertujuan untuk mereduksi biaya peluncuran agar efisien. Menurut studi Zapata dan Mccleskey, 2019, biaya peluncuran satelit sebesar 10.000 - 90.000 US\$/kg sebagaimana ditunjukkan dalam Gambar 2. Dengan melakukan analisis dan estimasi diharapkan dapat menentukan desain, dimensi, dan berat panel surya yang optimal untuk mengurangi biaya dalam pengembangan sistem satelit. 


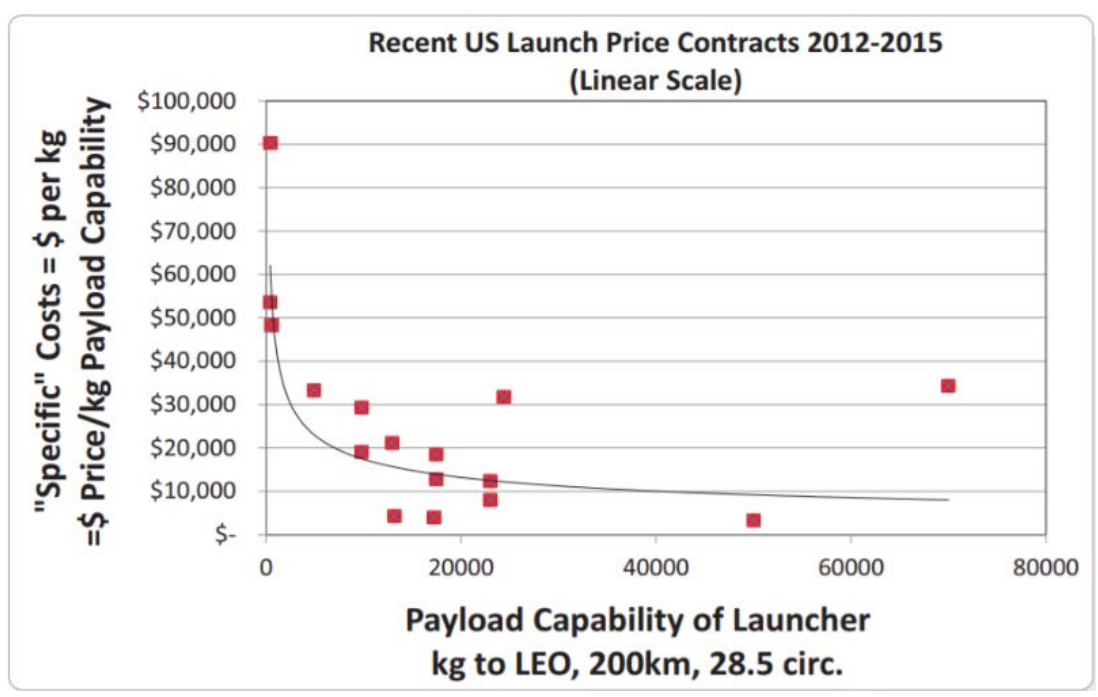

Gambar 2. Biaya Peluncuran Satelit (Zapata \& Mccleskey, 2019).

\section{METODOLOGI}

Langkah awal dalam penelitian ini yaitu melakukan perhitungan nilai iluminasi panel surya pada berbagai kondisi. Dengan mengetahui nilai iluminasi setiap panel dari panel surya, penulis dapat memprediksi besarnya daya yang dihasilkan berikut jumlah panel surya yang dibutuhkan oleh sebuah satelit untuk menjalankan semua subsistem satelit (bus dan payload) agar dapat menjalankan misi yang diemban. Iluminasi panel surya tersebut sangat tergantung pada tipe dan ketinggian orbit satelit sebagai penentu periode daylight dan eclipse. Oleh karena itu perlu ada batasan tipe dan ketinggian orbit dalam perancangan panel surya sebuah satelit. Untuk membantu memecahkan permasalahan nyata dalam perancangan satelit, studi ini mengambil kasus satelit orbit ekuatorial dengan ketinggian $600 \mathrm{~km}$.

Dalam satu periode orbit, satelit mengalami dua kondisi yaitu kondisi daylight dan kondisi eclipse. Kondisi daylight merupakan kondisi dimana satelit mendapatkan cahaya matahari, sedangkan kondisi eclipse adalah kondisi dimana satelit tidak mendapatkan cahaya matahari (Kim, dkk., 2017). Waktu eclipse yang dialami oleh satelit dengan ketinggian $600 \mathrm{~km}$ adalah \pm 36 menit dengan kecepatan angular satelit sebesar $0.062 \%$, sedangkan untuk periode daylight satelit adalah \pm 1 jam. Dengan bantuan perangkat lunak simulasi $A G I$ 's System Tool Kit(STK), dilakukan simulasi visualisasi satelit untuk menghasilkan data durasi daylight-eclipse (Kim, dkk., 2017) sebagaimana ditunjukkan Tabel 1.

Tabel 1. Periode Satelit dengan Ketinggian 600 km

\begin{tabular}{|l|c|}
\hline \multicolumn{1}{|c|}{ Keterangan } & nilai \\
\hline Periode orbit satelit (s) & 5790 \\
\hline Periode setengah orbit satelit (s) & 2895 \\
\hline Periode eclipse (s) & 2139 \\
\hline Persentase periode eclipse (\%) & 36.94 \\
\hline Periode daylight (s) & 3651 \\
\hline Persentase periode daylight (\%) & 63.06 \\
\hline Kecepatan angular satelit berotasi (deg/s) & 0.062 \\
\hline
\end{tabular}


Suryanti, dkk

\section{HASIL PEMBAHASAN}

Metode berbiaya rendah untuk perakitan panel surya serta pengembangan susunan panel surya yang fleksibel dan sederhana untuk dipasang pada platform satelit kecil masih menjadi topik penelitian terbuka. Biasanya, untuk satelit ukuran kecil, panel surya dimanufaktur menggunakan sel atau modul surya komersial, yang dihubungkan secara seri atau paralel tergantung pada kebutuhan sistem. Setelah operasi perakitan, kinerja dari panel surya harus dievaluasi dengan pengujian fungsional untuk mengidentifikasi kerusakan yang mungkin terjadi, karena sebagian besar masalah kegagalan mengenai subsistem daya satelit terkait dengan susunan sel surya (Rodiek \& Brandhorst, 2008)(Shekoofa, 2011).

Ada beberapa faktor utama yang mempengaruhi pemilihan dari sel surya, yaitu :

- Efisiensi sel tinggi. Sel surya yang memiliki efisiensi tinggi akan mengurangi area panel surya serta membantu mengurangi hambatan panel surya, dan secara tidak langsung akan memperpanjang usia dari satelit itu sendiri. Sel surya yang memiliki efisiensi tinggi juga dapat mengurangi massa dari panel surya, mengurangi biaya pembuatan panel surya dan dapat menghemat biaya peluncuran dari satelit tersebut.

- Resistansi radiasi yang lebih tinggi. Sel surya yang memiliki resistansi radiasi lebih tinggi dapat memberikan kehidupan misi yang lebih panjang, meningkatkan EOL (End of Life) satelit, serta memiliki sedikit aerodinamik karena area penampang solar panel yang lebih kecil. EOL merupakan sebuah informasi mengenai lamanya sebuah produk atau perangkat lunak masih dapat digunakan atau di akses.

- Koefisien suhu rendah.

- Ringan dan biaya rendah. Sel surya yang ringan dan berbiaya rendah dapat mengurangi massa sel surya serta mengurangi biaya peluncuran.

Telah diketahui bahwa power generator adalah masalah utama satelit kecil, yang memiliki keterbatasan pada ukuran, massa, dan luas permukaan untuk pemasangan panel surya (Mungiguerra, dkk., 2018). Selain itu hambatan aerodinamik juga menjadi salah satu masalah yang terjadi pada satelit dengan orbit rendah (LEO = Low Earth Orbit). Penggunaan panel surya sekecil mungkin dapat mengurangi masalah yang terjadi, jadi panel surya dengan efisiensi yang tinggi seperti GaAs menjadi pilihan yang menarik bagi perancangan satelit (Anspaugh, 1996).

Sel surya atau fotovoltaik adalah suatu alat yang mampu mengubah langsung cahaya matahari menjadi listrik. Sel surya dapat dianalogikan sebagai alat dengan dua terminal atau sambungan, yang mana ketika kondisi gelap atau tidak ada cahaya matahari berfungsi sebagai diode, dan ketika kondisi terang atau ada cahaya matahari dapat menghasilkan tegangan. Ketika disinari cahaya matahari satu sel surya untuk space menghasilkan tegangan DC sebesar 2.35 Volt dan arus 0.505 Ampere. Besar tegangan dan arus yang dihasilkan oleh 1 sel surya tidak dapat menutup besarnya kebutuhan tegangan setiap perangkat elektronik pada satelit dalam menjalankan misi yang diemban. Oleh karena itu pada sebuah satelit sel surya disusun secara seri dan pararel membentuk suatu modul surya yang biasa disebut panel surya. Panel surya tersebut kemudian digabungkan secara seri dan paralel untuk memperbesar total tegangan dan arus keluarannya sesuai dengan daya yang dibutuhkan untuk satelit dalam menjalankan misi yang diemban (Ramos-hernanz, dkk, 2017). Gambar 3 menunjukkan rangkaian seri sel surya yang bertujuan untuk meningkatkan tegangan. Gambar 4 menunjukkan rangkaian paralel sel surya yang bertujuan untuk meningkatkan kapasitas. Gambar 5 menunjukkan desain panel/modul surya dari sel-sel surya yang disusun secara seri dan paralel. 


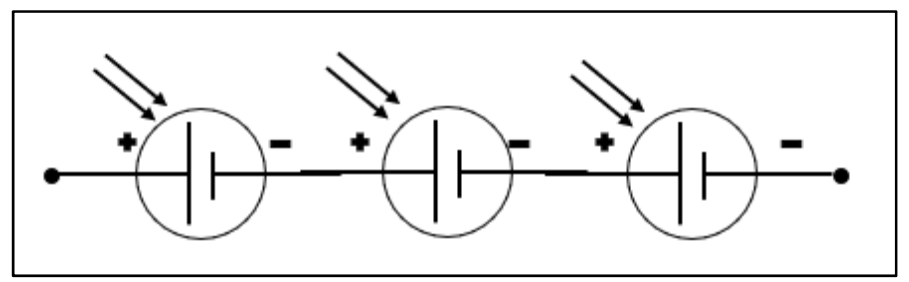

Gambar 3. Rangkaian Seri Sel Surya

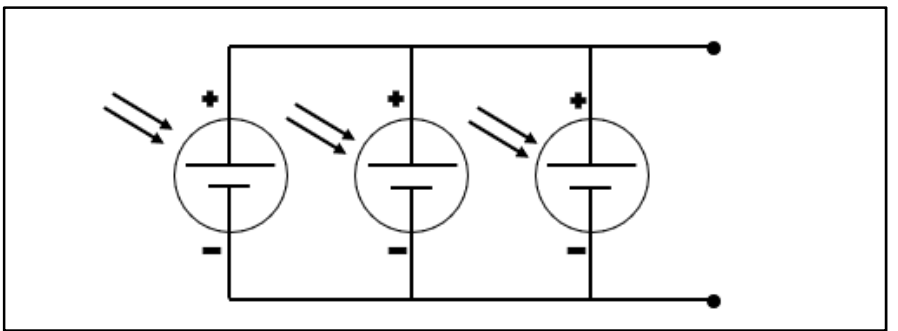

Gambar 4. Rangkaian Paralel Sel Surya

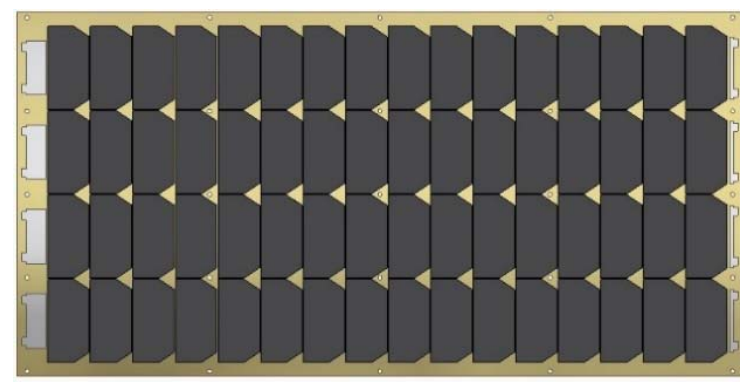

Gambar 5. Panel/Modul Surya pada Satelit LAPAN-A4 (Saifudin, dkk., 2018)

Gambar 6 menunjukkan ilustrasi besarnya iluminasi yang diterima oleh sebuah panel surya dipengaruhi oleh sudut datang (angle of incidence) yaitu sudut antara arah sinar matahari datang dengan komponen tegak lurus bidang panel. Dalam proses konversi energi listrik pada sel surya dipengaruhi banyak faktor yang dapat mengurangi optimalisasi pengonversian energi, diantaranya adalah faktor orientasi terhadap matahari yang selalu berubah-ubah.

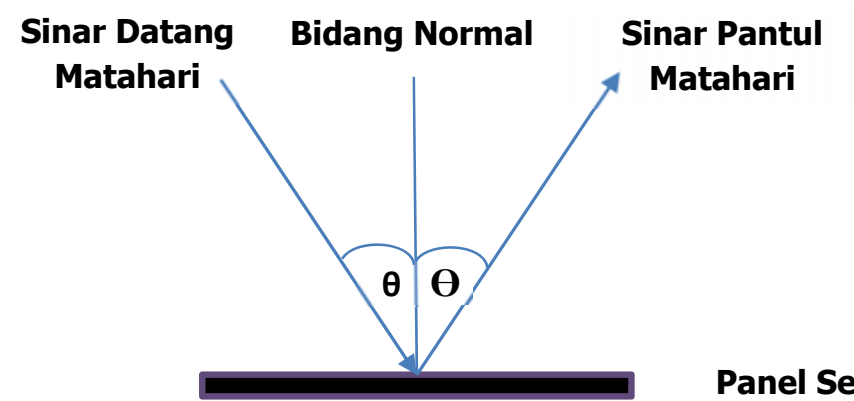

Gambar 6. Ilustrasi Ilumnasi yang Diterima Panel Surya terhadap Arah Datangnya Cahaya Matahari. 
Pada saat kondisi matahari bergeser ke utara atau selatan (solstice) maka daya yang dihasilkan oleh panel surya berkurang karena adanya inklinasi ke panel surya dari matahari sampai $23.50^{\circ}$ (Ippolito, 1986). Pada tahun 2019, Equinox terjadi pada 21 Maret dan 23 September sementara solstice terjadi pada 21 Juni dan 22 Desember. Gambar 7 menunjukkan keadaan equinox dan solstice di bumi. Equinox adalah suatu keadaan di bumi dimana waktu siang dan waktu malam sama panjangnya. Dalam satu tahun, equinox terjadi sebanyak dua kali yaitu pada saat musim gugur dan pada saat musim semi. Tepatnya setiap tanggal 21 Maret (Vernal Equinox) dan 23 September (Autumnal Equinox). Daerah di bumi yang mengalami waktu siang terpanjang dan siang terpendek pada suatu musim tertentu disebut solstice. Bagian bumi yang mengalami siang hari paling lama dinamakan summer solstice, sebaliknya bagian bumi yang mengalami waktu siang terpendek disebut winter solstice. Summer solstice terjadi pada 21 Juni, sedangkan winter solstice terjadi pada tanggal 22 Desember.

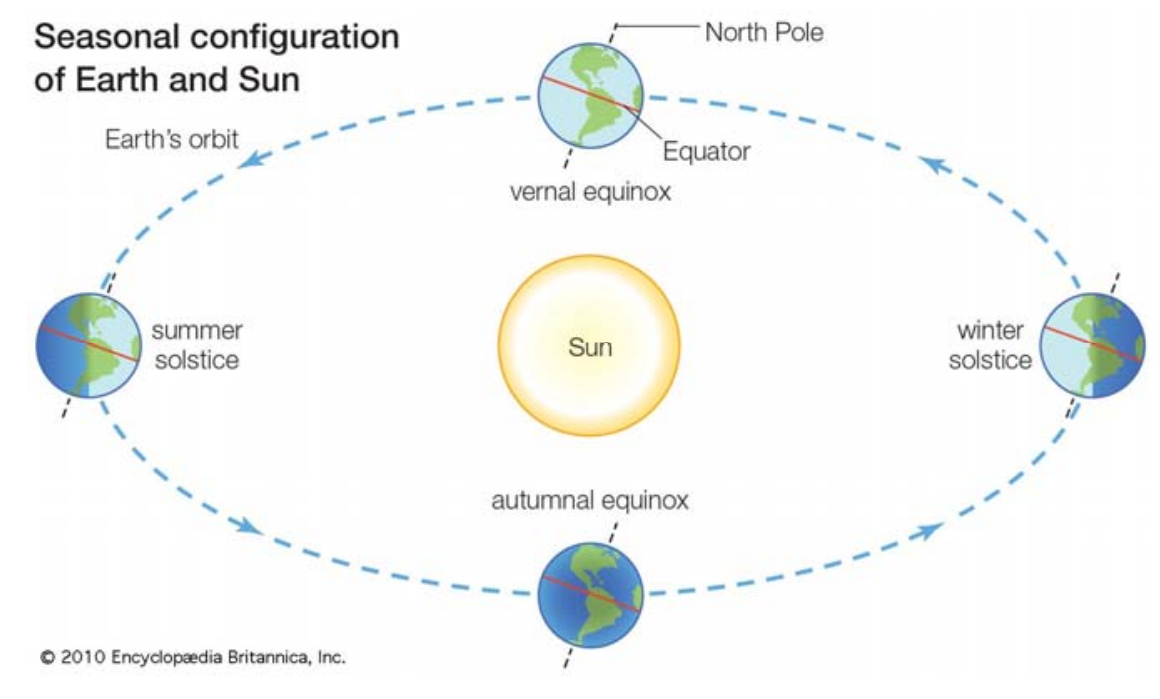

\section{Gambar 7. Kondisi Equinox dan Solstice di Bumi (Autumnal equinox _ astronomy _ Britannica, n.d.)}

Nilai iluminasi maksimum dicapai ketika panel surya tegak lurus terhadap arah datangnya sinar matahari. Pada kondisi solstice saat panel surya membentuk sudut terhadap arah datangnya matahari, maka nilai iluminasi dari panel surya tersebut berkurang $\pm 10 \%$ dari nilai maksimum. Nilai iluminasi $\left(I_{l}\right)$, dihitung menggunakan Persamaan (1) berikut:

$$
I_{l}=\cos \theta \cdot \cos \left(l a t_{\text {sun }}\right)
$$

$\theta=\omega \cdot t$

Dimana:

$\omega=$ kecepatan angular satelit, $0.062 \mathrm{deg} / \mathrm{sec}$ pada ketinggian $600 \mathrm{~km}$ lat $_{\text {sun }}=$ posisi latitude matahari

Grafik iluminasi matahari equinox dan solstice pada panel surya ketika satelit dalam kondisi nadir dapat dilihat pada Gambar 8. Semakin besar sudut yang dibentuk antara bidang panel surya dengan arah datangnya matahari maka nilai iluminasi dari panel surya tersebut semakin kecil dengan nilai minimum 0.917. 


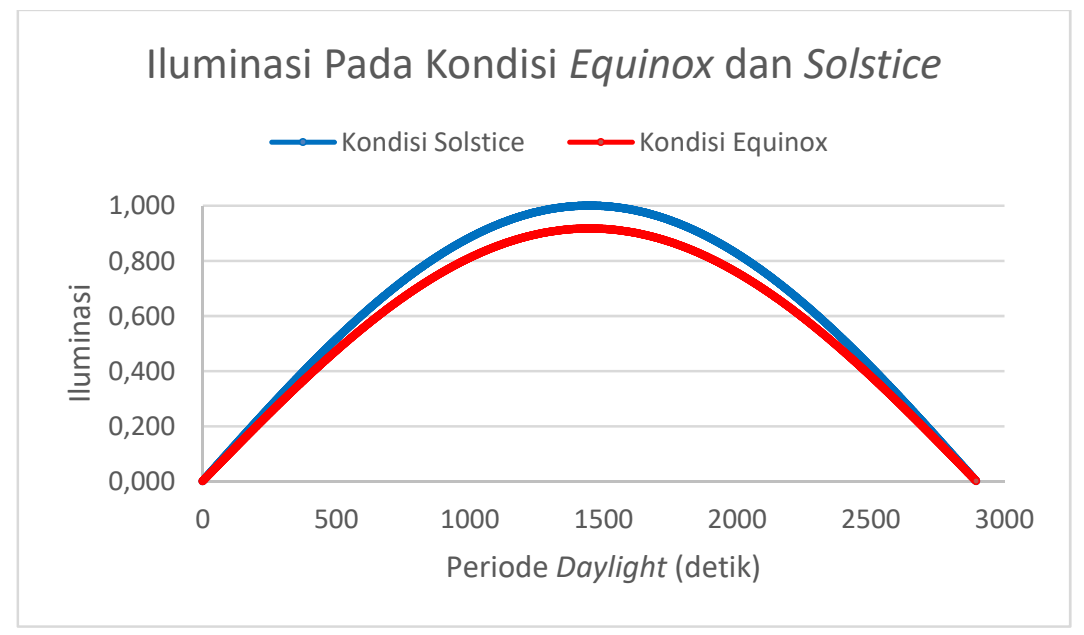

Gambar 8. Grafik Iluminasi Panel Surya pada Satelit

Kinerja susunan sel surya dalam hal daya yang dikirim rata-rata dalam satu orbit tergantung pada gerakan relatif matahari terhadap panel surya normal. Pada prinsipnya, orientasi panel surya dari susunan panel surya yang digunakan dapat dipilih untuk memaksimalkan daya ratarata yang dihasilkan termasuk ketika waktu eclipse (Santoni, dkk., 2014). Terlepas dari geometri orbit, kinerja susunan panel surya dapat ditingkatkan secara maksimal jika panel surya dapat berputar pada sumbu yang dipasang pada badan satelit (Santoni, dkk., 2014). Namun demikian desain panel surya yang berputar pada badan satelit menggunakan sun tracking mechanism cukup kompleks bagi sebuah satelit kecil sehingga menjadi alternatif terakhir dalam perancangan sistem daya satelit. Pemasangan panel surya dengan sun tracking mechanism tersebut melibatkan pengendalian motor dan roda gigi agar panel surya selalu menghadap ke arah datangnya sinar matahari (AL-Rousan, dkk., 2018).

Alternatif desain yang sederhana dan mudah diimplementasikan pada satelit kecil adalah body mounted dan simple deploy. Pada pemasangan secara body mounted, panel surya ditempatkan secara sederhana pada tiap sisi satelit. Sementara itu pada pemasangan panel surya secara simple deploy, panel akan mengembang sekali ketika satelit dilepaskan di orbit oleh roket peluncur. Gambar 9 menunjukkan berbagai konfigurasi pemasangan panel surya pada satelit.

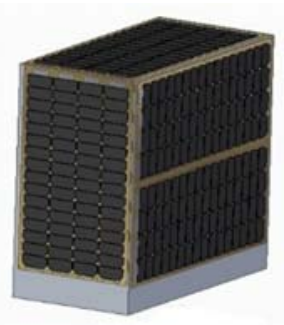

Body Mounted

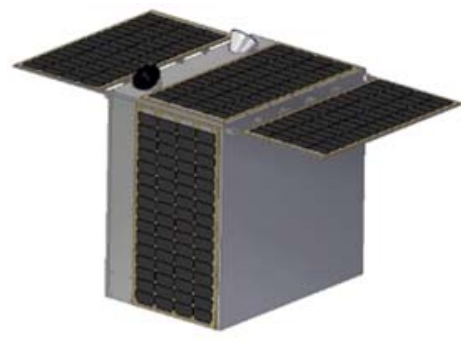

Simple Deploy

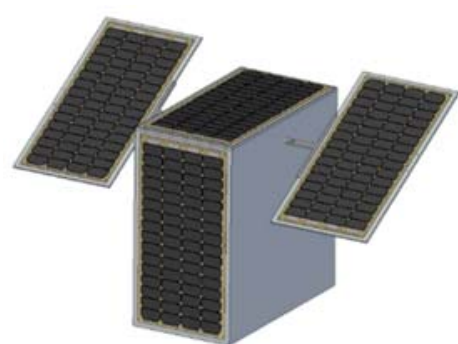

Sun Tracking

Gambar 9. Konfigurasi Penempatan Panel Surya pada Satelit

Gambar 10 menunjukkan variasi penempatan panel surya untuk mengetahui kondisi iluminasi matahari pada panel surya dari berbagai alternatif desain penempatan. 


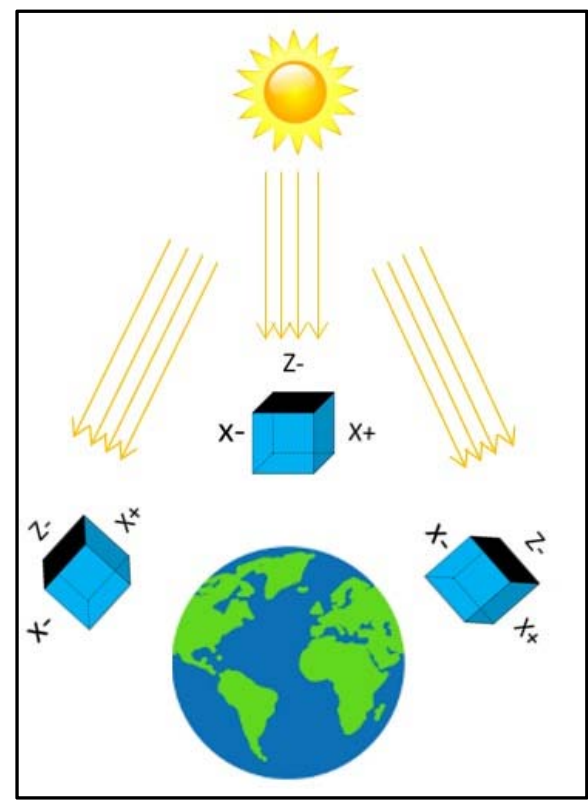

10(a)

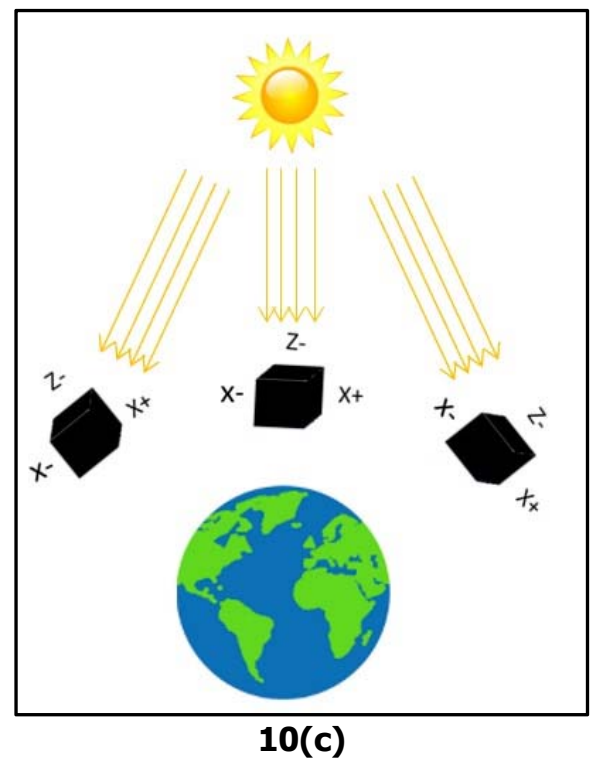

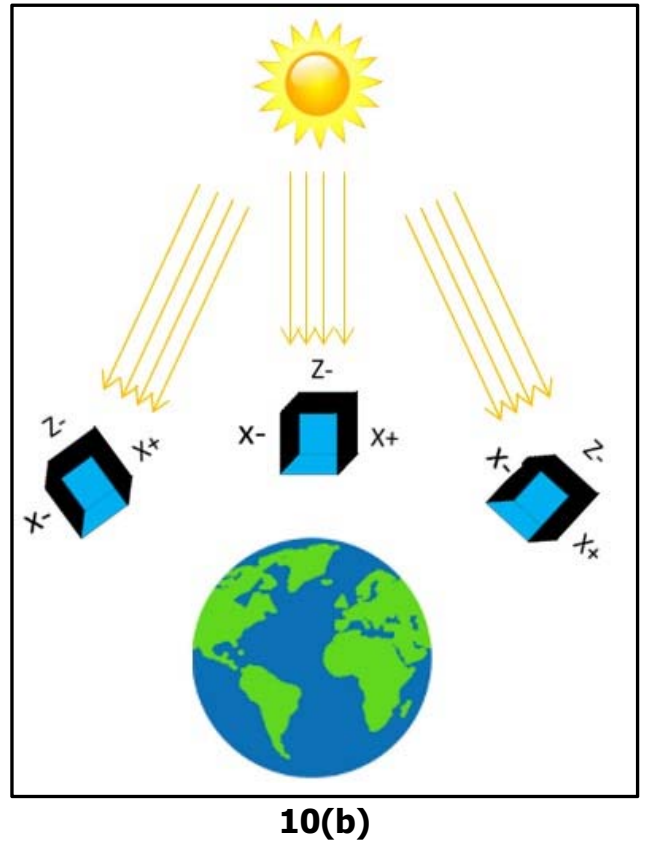

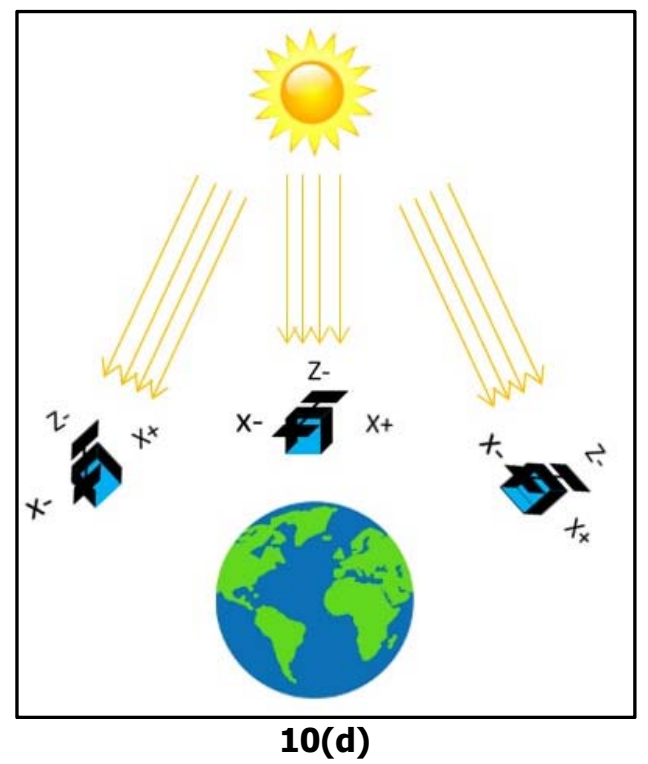

Gambar 10. Ilustrasi Iluminasi Panel Surya Ketika Satelit Dalam Keadaan Nadir dengan (a) Panel Surya Body Mounted 1 sisi, (b) Panel Surya Body Mounted 3 sisi, (c) Panel Surya Body Mounted 5 sisi, dan (d) Panel Surya Body Mounted 3 sisi dan 2 Panel Surya Simple Deploy

Gambar 10(a) menunjukkan sebuah panel surya pada sebuah satelit dalam kondisi nadir dimana panel surya ditempatkan pada bidang Z-. Iluminasi maksimum diterima panel surya ketika panel surya pada bidang Z- tegak lurus terhadap arah datang sinar matahari. Ketika bidangg Z- membentuk sudut $45^{\circ}$ terhadap arah datangnya sinar matahari, maka besarnya iluminasi dari panel surya $1 / 2$ dari iluminasi maksimum panel surya tersebut. 
Gambar 10(b) menunjukkan 3 buah panel surya yang masing-masing ditempatkan pada bidang X-, Z-, dan X+. Pada gambar tersebut, iluminasi maksimum diterima panel surya ketika panel surya pada bidang $\mathrm{X}+, \mathrm{Z}-$, dan $\mathrm{X}$ - tegak lurus terhadap arah datangnya sinar matahari.

Gambar 10(c) menunjukkan 5 buah panel surya yang masing-masing ditempatkan pada bidang $\mathrm{X}-, \mathrm{Z}-, \mathrm{X}+, \mathrm{Y}-$, dan $\mathrm{Y}+$. Pada gambar tersebut, iluminasi maksimum diterima panel surya ketika panel surya pada bidang $\mathrm{X}+$, Z- dan $\mathrm{X}$ - tegak lurus terhadap arah datangnya sinar matahari.

Gambar 10(d) menunjukkan 5 buah panel surya dimana 3 buah panel surya ditempatkan pada bidang X-, Z-, dan X+ serta 2 buah panel surya yang dipasang secara simple deploy dimana panel surya tersebut terhubung secara paralel ke engsel utama dengan struktur utama satelit (sejajar bidang Z-). Iluminasi maksimum terbesar terjadi ketika panel surya pada bidang Zserta dua buah simple deploy panel surya membentuk sudut tegak lurus terhadap arah datangnya sinar matahari.

Untuk membandingkan produksi daya yang dihasilkan oleh masing-masing konfigurasi perlu didefinisikan nilai perbandingan iluminasi $\left(I_{p}\right)$. Nilai $I_{p}$ merupakan hasil perbandingan antara jumlah total persentase iluminasi $\left(I_{t}\right)$ dengan iluminasi panel surya yang mengarah kepada matahari secara terus menerus $\left(I_{c}\right)$, dihitung menggunakan Persamaan (2) berikut:

$$
I_{p}=\frac{I_{t}}{I_{c}}
$$

Nilai $I_{p}$ dihitung pada saat equinox dan solstice dengan konfigurasi panel surya yang dipasang secara body mounted maupun simple deploy sebagaimana ditunjukkan pada Tabel 2. Tabel ini akan menjadi panduan generik dalam proses desain sistem daya sebuah satelit pada orbit ekuatorial dengan ketinggian $600 \mathrm{~km}$.

Tabel 2. Hasil Perhitungan Nilai Persentase Iluminasi dari Panel Surya

\begin{tabular}{|c|c|c|c|c|c|c|c|c|}
\hline \multirow{2}{*}{ Parameter } & \multicolumn{2}{|c|}{ Konfigurasi A } & \multicolumn{2}{c|}{ Konfigurasi B } & \multicolumn{2}{c|}{ Konfigurasi C } & \multicolumn{2}{c|}{ Konfigurasi D } \\
\cline { 2 - 9 } & \multicolumn{2}{|c|}{ 1 Panel BM } & \multicolumn{2}{c|}{ 3 Panel BM } & \multicolumn{2}{c|}{ 5 Panel BM } & \multicolumn{2}{c|}{$\begin{array}{c}\text { 3 Panel BM + } \\
\text { 2 Panel SD }\end{array}$} \\
\cline { 2 - 9 } & Equinox & Solstice & Equinox & Solstice & Equinox & Solstice & Equinox & Solstice \\
\hline$I_{p}$ & $63.63 \%$ & $58.38 \%$ & $127.32 \%$ & $116.76 \%$ & $127.32 \%$ & $156.64 \%$ & $254.65 \%$ & $233.53 \%$ \\
\hline $\begin{array}{c}\text { Jumlah panel } \\
\text { tracking untuk } \\
\text { mendapatkan } \\
\text { iluminasi yang } \\
\text { setara }\end{array}$ & 0.64 & 0.58 & 1.27 & 1.17 & 1.27 & 1.57 & 2.55 & 2.34 \\
\hline
\end{tabular}

Note: $\mathrm{BM}=$ Body Mounted

$\mathrm{SD}=$ Simple Deploy

Berdasarkan Tabel 2, iluminasi maksimum sebuah panel surya triple junction yang terpasang secara body mounted pada satelit kurang lebih sebesar $60 \%$. Iluminasi yang diperoleh konfigurasi A pada saat equinox setara dengan 0.64 panel surya yang mengarah ke matahari secara terus-menerus, sedangkan pada saat solstice setara dengan 0.58 panel surya yang mengarah ke matahari secara terus-menerus. Iluminasi yang diperoleh konfigurasi $\mathrm{C}$ pada saat solstice setara dengan 1.57 panel yang mengarah ke matahari secara terus-menerus. Ini berarti desain yang menggunakan 2 buah panel surya dengan sun tracking mechanism bisa menjadi alternatif untuk menggantikan konfigurasi $C$ dengan hasil iluminasi yang lebih baik. Berdasarkan Tabel 2 tersebut juga terlihat bahwa iluminasi dari konfigurasi $C$ nilainya lebih kecil dari pada konfigurasi $D$ walaupun jumlah panelnya sama. 
Misal, dalam sebuah operasi satelit dibutuhkan daya 150 Watt. Jika terdapat satu buah panel yang menghasilkan daya sebesar 100-Watt maka jumlah panel yang dibutuhkan dengan sun tracking mechanism adalah 1.5. Dengan demikian konfigurasi yang dapat digunakan adalah konfigurasi $D$. Karena konfigurasi $C$ hanya memenuhi kebutuhan operasi satelit pada saat solstice. Jadi analisis iluminasi sebagaimana yang ditunjukkan pada Tabel 2 dapat membantu mempercepat pemilihan konfigurasi panel surya pada sistem daya satelit, apakah harus menggunakan panel surya yang dipasang secara body mounted, simple deploy, atau sun tracking.

Berdasarkan hasil penelitian ini, pada studi kasus satelit dengan orbit ekuatorial, walaupun menggunakan jumlah panel yang sama kombinasi pemasangan 3 body mounted panel surya dan 2 simple deploy panel surya menghasilkan persentase iluminasi dua kali lipat dibandingkan 5 body mounted panel surya.

\section{KESIMPULAN}

Nilai iluminasi matahari terhadap sebuah bidang panel surya tidak akan pernah mencapai nilai maksimal $100 \%$ dimana cahaya matahari datang tegak lurus terhadap bidang panel surya secara terus menerus. Iluminasi $100 \%$ hanya bisa tercapai jika panel surya memiliki sun tracking mechanism yang memiliki kompleksitas tinggi. Alternatif penempatan panel surya yang sederhana menggunakan cara body mounted atau simple deploy. Analisis iluminasi yang tersaji dalam Tabel 2 akan membantu penentuan konfigurasi pemasangan panel surya dalam perancangan sistem daya satelit, apakah dipasang secara body mounted, simple deploy ataukah harus sun tracking. Dengan demikian satelit bisa mendapatkan daya yang digunakan untuk menjalankan misi yang diemban dengan jumlah yang efisien.

\section{UCAPAN TERIMA KASIH}

Penulis mengucapkan terima kasih kepada Bapak Mujtahid sebagai Kepala Pusat Teknologi Satelit LAPAN sehingga karya tulis ini dapat terlaksana dengan baik. Penulis juga mengucapkan terima kasih kepada tim Redaksi Jurnal ELKOMIKA.

\section{DAFTAR RUJUKAN}

AL-Rousan, N., Isa, N. A. M., \& Desa, M. K. M. (2018). Advances in solar photovoltaic tracking systems: A review. Renewable and Sustainable Energy Reviews, 82(3), 2548-2569.

Anigstein, P. A., \& Sánchez Peña, R. S. (1998). Analysis of solar panel orientation in low altitude satellites. IEEE Transactions on Aerospace and Electronic Systems, 34(2), 569-578.

Anspaugh, B. E. (1996). GaAs Solar Cell Radiation Handbook. National Aeronautics and. Space Administration JPL.

Encyclopaedia $\quad$ Britannica. (2012). Retrieved from https://www.britannica.com/science/autumnal-equinox/media/1/45236/112844.

Ippolito, L. (1986). Communications Atmospheric Effects, Satellite Link Design.

James, J. J., Wertz, R. R., \& Larson, W. J. (1999). Wertz Mission Geometry; Orbit and 
Constellation Design and Management, James R. Wertz Influence of Psychological Factors on Product Development. Retrieved from https://theeye.eu/public/WorldTracker.org/Space/Space Engineering/Space_Mission_Analysis_and_Design.pdf

Karim, A., \& Hasbi, W. (2013). Analisis Dan Pengujian Sistem Baterai Satelit LAPAN-A2/ORARI. Jurnal Teknologi Dirgantara, 11(2), 159-165.

Kim, E. J., Sim, E. S., \& Kim, H. D. (2017). Development of the power simulation tool for energy balance analysis of nanosatellites. Journal of Astronomy and Space Science, 34(3), 225-235.

Loh, K. (1991). Solar Cells for Space Applications. 235, 63-67.

Luceño-Sánchez, J. A., Díez-Pascual, A. M., \& Capilla, R. P. (2019). Materials for photovoltaics: State of art and recent developments. International Journal of Molecular Sciences, 20(4). 976.

Mungiguerra, S., Zuppardi, G., Spanò Cuomo, L., \& Savino, R. (2018). Effects of solar panels on Aerodynamics of a small satellite with deployable aero-brake. Acta Astronautica, $151,456-466$.

NREL. (2019). Best Research-Cell Efficiency Chart | Photovoltaic Research | NREL. National Renewable Energy Laboratory. Retrieved from https://www.nrel.gov/pv/cellefficiency.html

Park, H., \& Cha, H. (2016). Electrical design of a solar array for LEO satellites. International Journal of Aeronautical and Space Sciences, 17(3), 401-408.

Ramos-hernanz, J., Lopez-guede, J. M., \& Zulueta, E. (2017). Reverse Saturation Current Analysis in Photovoltaic Cell Models. WSEAS Transactions on Power Systems, 12, 231237.

Ray, S. N. (1963). The physics of space research. In British Journal of Applied Physics, 14(2). 77-78.

Rodiek, J. A., \& Brandhorst, H. W. (2008). Solar array reliability in satellite operations. 2008 33rd IEEE Photovoltaic Specialists Conference, (pp. 1-4).

Saifudin, M. A., Karim, A., \& Mujtahid. (2018). LAPAN-A4 Concept and Design for Earth Observation and Maritime Monitoring Missions. ICARES 2018 - Proceedings of the 2018 IEEE International Conference on Aerospace Electronics and Remote Sensing Technology, (pp. 44-48).

Santoni, F., Piergentili, F., Donati, S., Perelli, M., Negri, A., \& Marino, M. (2014). An innovative deployable solar panel system for Cubesats. Acta Astronautica, 95(1), 210-217. 
Shekoofa, O. (2011). Solar arrays testing for space applications. RAST 2011 - Proceedings of 5th International Conference on Recent Advances in Space Technologies, (pp. 560565).

Zapata, E., \& Mccleskey, C. (2019). An Analysis and Review of Measures and Relationships in Space Transportation Affordability. AIAA Joint Propulsion Conference. Retrieved from https://ntrs.nasa.gov/archive/nasa/casi.ntrs.nasa.gov/20140011200.pdf. 